\title{
A SOCIAL COST BENEFIT ANALYSIS OF EXTENDING AN EXISTING RECYCLING PLANT TO ACCOMMODATE THE RECYCLING OF THE PLASTIC FRACTION OF CABLE SCRAP
}

\author{
M. du Preez ${ }^{1}$ \\ Department of Economics \\ Nelson Mandela Metropolitan University, South Africa. \\ mario.dupreez@nmmu.ac.za \\ T. Lottering ${ }^{2}$ \\ Aberdare Power Cables, South Africa \\ tony.lottering@transnet.net
}

\begin{abstract}
This paper investigates the economic efficiency of extending an existing cable waste recycling plant to accommodate the recycling of the plastic fraction of cable waste. The paper shows that when a cost benefit analysis (CBA) is carried out, the decision-making criteria generate conflicting results. More specifically, the net present value (NPV) is greater than zero, the internal rate of return (IRR) is less than the social discount rate, and the benefit cost ratio (BCR) is less than unity. Based on these results, one is unable to provide unqualified support for the project.
\end{abstract}

\section{OPSOMMING}

Die navorsing word toegespits op die uitbreiding van ' $n$ bestaande kabelskrootaanleg vir die herwinning van plastiekafval. Koste-opbrengs-ontleding (CBA) toon dat toepaslike kriteria soos interne rentabiliteit (IRR) en koste-opbrengs-verhouding (BCR) nie die uitbreiding onomwonde ondersteun nie.

\footnotetext{
${ }^{1}$ Corresponding author

${ }^{2}$ The author was enrolled for an MCom degree at the Department of Economics, Nelson Mandela Metropolitan University
} 


\section{INTRODUCTION}

The Basel Convention is the key driver in the promulgation of European Union (EU) environmental legislation. One of the principal aims of the Basel Convention is to promote the safety of human health and sustainable development. To this end, many governments have legislated for cleaner production and responsible waste management practices. One of the main features of the legislation is limiting the amount of waste going to landfill sites through promoting the mechanical recycling of plastic [1].

With the re-entry of South Africa into the global market, it has become imperative that manufacturing companies adopt a responsible attitude to waste prevention and waste minimisation, so as to conform to international standards and legislation. In line with international standards, the South African Government has issued a White Paper on integrated pollution and waste management for South Africa [2]. This is a policy document on pollution prevention, waste minimisation, impact management, and remediation. A National Waste Management Strategy [2] has been developed that is linked to the White Paper, and this document sets out a waste hierarchy ${ }^{1}$ consisting of four tiers, in descending order:

- $\quad$ Cleaner production (waste prevention, waste minimisation);

- $\quad$ Recycling (re-use, recovery, composting);

- $\quad$ Treatment (physical, thermal and chemical destruction); and

- $\quad$ Disposal (land filling).

South African exports of manufactured goods to Europe, for example, are substantial. For the period January to September 2005, South African exports to Europe amounted to R87 billion [3]. The South African export industry, while not a signatory to the Basel Convention, is required to conform to the standards laid down by it.

The well-developed cable manufacturing industry in South Africa produces for both local and export markets, with nine manufacturing companies situated throughout the country [4]. In 2002, the South African cable manufacturing industry produced electrical and communication cable to the value of R2.4 billion [3] ${ }^{2}$. Of this, $95 \%$ is destined for the local market, while $5 \%$ is exported - most of it to the rest of the African continent.

The production of electrical and telecommunication cable, however, leads to the creation of scrap (i.e. waste cable).

The industry generates in excess of 500 tons of insulated telecommunication cable scrap each year [5]. This scrap contains, on average, about $60 \%$ metal and $40 \%$ plastics. The conducting material in this scrap is primarily copper [1].

The value of the metal conductor (copper or aluminium) used in the manufacture of electrical and telecommunication cable ensures that it will always be recovered from the cable scrap. The plastic insulation and sheathing material contained in the telecommunication cable scrap can be disposed of by landfill or incineration, or recycled by mechanical means. At present, incineration is not used as a disposal method in South Africa as the cost is higher than that of landfill ${ }^{3}$. Adherence to international protocols requires the South African cable manufacturing industry to recycle waste instead of land-filling it. There is, however, a paucity of published studies that establish the economic rationale for the recycling of cable scrap. This study aims to fill this gap.

\footnotetext{
${ }^{1}$ A waste hierarchy is a list of approaches in managing waste in order of preference from most desired to least desired [2].

${ }^{2}$ These are the latest figures available from Statistics South Africa.

${ }^{3}$ Figures for the cost of incineration were only available for Europe. This form of disposal is not widely practised in South Africa, other than with medical waste.
} 
The existing plant can be viewed as the 'without', scenario while the extension is the 'with' scenario. The net benefit arising from the project will simply be the difference between the 'with' and 'without' scenarios. The approach taken to achieve this aim entails identifying and estimating (where possible) the social costs and social benefits that will arise from the extension of an existing cable waste recycling plant in order to allow recycling of the plastic component of cable waste.

\section{COST-BENEFIT ANALYSIS}

Cost-benefit analysis (CBA) is a standard method for determining and comparing the social costs and social benefits of an investment project. The measured costs and benefits are weighed up against each other to establish criteria for decision-making. Normally one or more of the following decision-making criteria are used:

The net present value (NPV) of a project expresses the difference between the discounted present value of total benefits and the discounted present value of total costs. The Net Present Value (NPV) is represented by

$\mathrm{NPV}=\sum_{\mathrm{t}=0}^{\mathrm{n}} \frac{\mathrm{B}_{\mathrm{t}}-\mathrm{C}_{\mathrm{t}}}{(1+\mathrm{i})^{\mathrm{t}}}$

where:

$\mathrm{NPV}=$ net present value

$\mathrm{B}_{\mathrm{t}}=$ benefit in year $\mathrm{t}$

$\mathrm{C}_{\mathrm{t}}=$ cost in year $\mathrm{t}$

$(1+i)^{t}=$ discount factor used to discount $B_{t}$ and $C_{t}$ to present values

$\mathrm{n}=$ length of the project

The internal rate of return (IRR) is that discount rate that, when applied to the net benefit stream, will cause the NPV of a project to equal zero [6]. The IRR rule, for the acceptance of a project, requires that the IRR be greater than the social discount rate [6]. The IRR is shown as the discount rate $i$ in the equation below.

$$
\sum_{t=0}^{n} \frac{B_{t}-C_{t}}{(1+i)^{t}}=0
$$

The benefit cost ratio $(B C R)$ of a project is the ratio of the present value benefits to the present value costs, and can be formally expressed as follows:

$$
B C R=\frac{\sum_{t=0}^{n} \frac{B_{t}}{(1+i)^{t}}}{\sum_{t=0}^{n} \frac{C_{t}}{(1+i)^{t}}}
$$

An investment project is deemed to be acceptable if the NPV is positive, or if the IRR exceeds the applicable social discount rate, or if the BCR exceeds unity.

There are four standard elements to CBA: time considerations, costs, benefits, and the social discount rate. All of these are discussed below. 


\subsection{Time considerations}

All the estimated social cost and social benefit flows derived in this study are captured in per annum periods and expressed at 2005 price levels. A distributional weighting of 1 was used for all cross-sectional costs and benefits over the full project period. This weighting assumes that a Rand benefit is worth the same to all members of the population affected by the project in question. The project period or time horizon of the project was set at 20 years.

\subsection{The social costs of recycling the plastic fraction of cable scrap}

The social costs comprise primary and secondary costs that can be ascribed to the extension of an existing mechanical recycling project, to allow for the recycling of plastic scrap. These are examined below, and, where possible, a monetary value is attached to them.

\section{Primary costs}

The primary costs incurred in extending a waste cable recycling plant to accommodate plastic recycling can be broken down into capital costs and operating and maintenance costs. These costs are discussed below.

\section{Capital costs}

The capital costs include all those for machinery purchases, as well as installation costs. A large portion of the capital costs, such as the purchase of the land, erection of the buildings, and the supply of services, is viewed as sunk $\operatorname{costs}^{4}$ : an existing cable waste recycling plant is simply extended to accommodate the recycling of plastic.

The only capital cost involved in the recycling of plastic scrap is the purchase of an extruder. It is important to note that this is imported from Europe, and so the purchase price is quoted in euros. The average exchange rate for the period January 2005 to January 2006 was R8.021/ $€$, with a high of R9.49/ $€$ and a low of R6.55/ $€$. The average exchange rate was used to convert the euro price into a Rand equivalent. The cost of acquiring and installing the extruder comes to R800,000.

\section{Operating and maintenance costs}

The operating and maintenance costs include those for electricity, water, machinery maintenance, and salaries and wages. The total annual cost of electricity consumption amounts to R72,366 (see Appendix A).

The cost of water for recycling plastic is zero since the cost is incorporated into the cost of recycling the conductor. The reason for this assumption is that the extrusion process makes use of a closed circuit water cooling system ${ }^{5}$. As a result, the only water used is make-up water, and this is negligible. The following components of the extruder used in the plastic recycling division require regular maintenance and replacement: the heating elements, fuses, motor rewinds, bearings, and relays. The total annual maintenance budget for the plastic recycling process amounts to R70,200. Two employees are required to run the extrusion process, with an annual wage and salary bill of R74,339. The purchase of the

\footnotetext{
${ }^{4} \mathrm{~A}$ 'sunk cost' is one that has already been incurred - in this case, costs that arose prior to the project case being embarked on.

${ }^{5} \mathrm{~A}$ closed loop system involves re-using the same cooling water repeatedly. The water is pumped from a tank to the extruder and back to the tank via a cooling tower. The only other water that is used replenishes the system due to the evaporative cooling effect in the cooling tower.
} 
scrap cable is already undertaken for the recycling of the copper component of cable waste, and as such, does not entail a cost for the extension of the existing plant.

The primary costs are shown in Table 1 below:

PRIMARY COSTS

\begin{tabular}{|l|r|}
\hline Capital Costs & \\
\hline Extrusion machine & $\mathrm{R} 800,000.00$ \\
\hline Total capital cost & $\mathrm{R} 800,000.00$ \\
\hline Operating and maintenance costs & \\
\hline Electricity kVA & $\mathrm{R} 49,200.00$ \\
\hline Electricity kWh & $\mathrm{R} 23,166.00$ \\
\hline Maintenance & $\mathrm{R} 70,200.00$ \\
\hline Operational staff & $\mathrm{R} 74,339.00$ \\
\hline Total annual operating and maintenance cost & $\mathrm{R} 216,905.00$ \\
\hline
\end{tabular}

Table 1: Primary costs

\section{Secondary costs}

In addition to the primary costs, there are those that arise from external effects (externalities) created by the plastic recycling process. These costs are not accounted for in the establishment or the running of the extended plastic recycling division.

All identified negative externalities (costs) are discussed below.

a) Costs related to the generation of greenhouse gases and asthma

The principle source of air pollution arising from the plastic recycling project will be in the extrusion of the recyclate. When extruding PVC, chlorine fumes are given off. There is a possibility that the chlorine fumes could create an incidence of occupational asthma in operating staff, due to the irritation effect of the fumes. However, tests have found that the effect of the PVC fumes on the environment and on humans is minimal when there is adequate ventilation [5]. No cost was attached to this externality.

\subsection{The social benefits of recycling of the plastic fraction of cable scrap}

The social benefits (primary and secondary) that can be associated with the extension of a mechanical cable waste recycling project, so as to accommodate the recycling of plastic, are examined below, and a monetary value is, where possible, attached to them.

\section{Primary benefits}

The primary benefit is the revenue generated by the re-use of granulated PVC and PE for the manufacture of fence poles at the facility. There is a ready market for the sale of PVC fence droppers [5]. There is also a market within the farming community - and the advantage of these poles is that they do not rust and cannot be used for fuel. Added to this is the fact that the scrap PVC has carbon black as an additive that enhances its UV stability. This revenue amounts to R254,097 per annum (see Appendix B). 


\section{Secondary benefits}

Two secondary benefits have been identified. They are: an increase in the prices of houses situated close to a landfill, due to the recycling of the plastic component of cable waste, and the avoidance of landfill cost. These are discussed below.

a) Value added to properties using the Hedonic Pricing Method (HPM)

The theory of the hedonic pricing method (HPM) was advanced by Lancaster [7] and Rosen [8]. The hedonic pricing method is based on consumer theory, in that a good is valued according to its specific attributes or characteristics, represented as a vector $B$. The elements of $B$ are typically composed of physical $\lambda$, location $\theta$, and environmental attributes $\epsilon$. The physical attributes could include the size of the house, the number of rooms, the presence of outbuildings, and its age. The location would refer to the proximity of the house to amenities and facilities. The environmental attributes could include the quality of the air, road noise, and proximity to a landfill (not all attributes need be positive).

The effect that land usage has on residential property values has long been a source of public debate. Negative externalities, created by the injudicious use of land, may have a negative impact on property values. These externalities take the form of air, water, noise, and soil pollution, and can give rise to bad odours, vermin and flies, with the associated sickness that accompanies them. Because of these negative impacts, it is normal to site industries that may have a deleterious effect, from an aesthetic as well as health point of view, in areas remote from residential neighborhoods, and to create buffer zones to prevent future encroachment. Landfills can be viewed as creating a negative externality. The operations that take place at a landfill that contribute to this perception are the dumping of municipal waste comprised of decomposing organic material. This waste releases bad odours and landfill gas, and the covering and compacting of the waste with soil creates airborne dust.

The economic impact that a landfill has on the value of properties in its vicinity is important for a number of reasons. First, the difference in value between like properties, different only in their distance from a landfill, gives an indication of the welfare impact that the landfill has on nearby properties [9]. Second, property owners want to know what effect, if any, proximity to a landfill will have on the value of their assets. Third, the effect that a landfill has on property values can be used in a CBA [9].

The HPM was applied by gathering data on residential properties situated in close proximity to a disused landfill in the New Brighton area within the Nelson Mandela Metropolitan Municipality. The site was used as a landfill from 1981 to 2001 . The site is presently under the control of the Nelson Mandela Metropolitan Municipality.

A hedonic pricing method study carried out found that there is a definite correlation between house values and proximity to the landfill. The closer houses are situated to the landfill, the lower their prices. The social benefit realised in terms of recycling the plastic fraction of cable waste instead of land filling it, and thus increasing house prices, amounts to R2,942.88 [10].

b) Avoidance of landfill costs

The assumption is that all the plastic will be recycled. The plastic fraction of the cable waste constitutes 91,200 kilograms of scrap. The cost of disposal in landfill is R47.30 per ton, equating to a total annual cost saving of R4,313.00 [5]. 


\subsection{The social discount rate}

The net benefits of a project that occur over time must be converted into a standard of comparison. This is achieved by determining the present values of all present and future net benefits. A discounting formula, which incorporates a discount rate $^{6}$, is used to estimate present values. More formally, this formula can be expressed as follows:

$$
P V=\sum_{t=0}^{n} \frac{N B_{t}}{(1+i)^{t}}
$$

where:

$\mathrm{PV}=$ present value of all net benefits

$N B=$ net benefits accruing from the project in time period $t$

$\mathrm{t}=$ time period $\mathrm{t}$

$\mathrm{i}=$ discount rate

Two types of discount rates can generally be distinguished: the social time preference rate, and the social opportunity cost of capital rate.

Due to market imperfections in capital markets and the existence of multiple interest rates, the social opportunity cost of capital (SOCC) is usually not the same as the social rate of time preference (SRTP). The social discount rate needs to reflect this and must, as such, be derived from a number of sources of funding to reflect both the SOCC and the STPR components. In publicly-funded projects the finance is obtained from government, which in turn acquires it by means of borrowing and taxes. By their very nature, taxes require that households and corporations forego consumption and savings in order to pay them. The cost of 'lost' consumption is measured by the prevailing interest rate at which consumers are willing to borrow, and the cost of 'lost' savings is measured as the foregone yield on dividends and interest earned on savings. Government borrowing also has a cost: the interest paid to purchasers of government bonds. Based on the discussions above, the social discount rate can, therefore, be estimated from the equation below.

$\mathrm{i}=\mathrm{t}\left[(1-\mathrm{s})\left(\mathrm{X}_{1}-p\right)+(s)\left(X_{2}-p\right)\right]+\left[(1-t)\left(X_{3}-p\right)\right]$

where:

$t=$ fraction of public expenditure financed by tax and duties

$(1-t)=$ fraction of public expenditure financed by borrowings

$\mathrm{s}=$ fraction of disposable income saved

$(1-s)=$ fraction of disposable income consumed

$\mathrm{X}_{1}=$ the average of the prime overdraft rate and the term lending rate, also known as the hire-purchase credit rate

$\mathrm{X}_{2}=$ the average dividend yield and capital growth of all listed shares on the JSE

$X_{3}=$ the average of the government loan stock yield (ten years and over) and the Eskom bond rate

$p=$ the inflation rate $[11]$.

Using the above formula and data displayed in Tables 2, 3, and 4 below, the real social discount rate was estimated at $6.72 \%$.

\footnotetext{
${ }^{6}$ The discount rate can be defined as the rate of interest that is used to determine the present value of a project or investment.
} 


\begin{tabular}{|c|c|c|c|c|c|c|c|c|c|c|}
\hline \multicolumn{4}{|c|}{$\begin{array}{l}\text { Cost of government } \\
\text { borrowing }\end{array}$} & \multicolumn{3}{|c|}{$\begin{array}{l}\text { Cost of household } \\
\text { consumption borrowing }\end{array}$} & \multicolumn{3}{|c|}{$\begin{array}{c}\text { Return } \\
\text { on savings }\end{array}$} & \multirow{2}{*}{\begin{tabular}{|c} 
Average \\
annual \\
inflation \\
rate as \\
measured \\
by \\
consumer \\
price index \\
$\%$
\end{tabular}} \\
\hline Year & $\begin{array}{c}\text { Government } \\
\text { stock- yields on } \\
\text { loan stock } \\
\text { traded on the } \\
\text { bond exchange } \\
(>10 \text { years }) \% \\
\text { (a) }\end{array}$ & \begin{tabular}{|c|} 
Eskom \\
Bond \\
Yield, \% \\
\\
(b)
\end{tabular} & $\begin{array}{c}\begin{array}{c}\text { Average } \\
\text { yield, \% }\end{array} \\
\frac{\text { (a) +(b) }}{2} \\
X_{3}\end{array}$ & \begin{tabular}{|} 
Predominant \\
overdraft \\
rate on \\
current \\
accounts \% \\
\\
(c)
\end{tabular} & $\begin{array}{l}\text { Long-term } \\
\text { lending base } \\
\text { rate } \\
\text { (installment } \\
\text { plan credit) \% } \\
(1180 \mathrm{M} \\
\text { \& } 1182 \mathrm{M})^{1} \\
\text { (d) }\end{array}$ & $\begin{array}{l}\begin{array}{c}\text { Average } \\
\text { rate } \% \\
(\mathrm{c})+(\mathrm{d})\end{array} \\
2\end{array}$ & $\begin{array}{c}\text { Dividend } \\
\text { yield \% }\end{array}$ & $\begin{array}{c}\text { Capital } \\
\text { growth } \\
\%\end{array}$ & $\begin{array}{c}\begin{array}{c}\text { Average } \\
\% \\
(\mathrm{e})+(\mathrm{f}) \\
2\end{array} \\
\mathrm{X}_{2}\end{array}$ & \\
\hline 2001 & 11.63 & 12.03 & 11.83 & 13.0 & 13.0 & 13 & 3.04 & 24.3 & 13.67 & 6.6 \\
\hline 2002 & 10.44 & 11.22 & 10.88 & 15.75 & 14.02 & 14.88 & 3.4 & -6.3 & -1.45 & 9.3 \\
\hline 2003 & 9.15 & 9.08 & 9.12 & 17.10 & 14.43 & 15.77 & 3.88 & 4.9 & 4.39 & 6.8 \\
\hline 2004 & 8.38 & 8.16 & 8.27 & 14.36 & 11.25 & 12.8 & 2.94 & 23.1 & 13.02 & 4.3 \\
\hline 2005 & 7.51 & 7.55 & 7.53 & 14.15 & 10.38 & 12.27 & 2.68 & 39.9 & 21.29 & 3.9 \\
\hline
\end{tabular}

Table 2: Cost of government borrowing, cost of household consumption borrowing, return on savings, and the annual inflation rate (2001-2005)

Sources: [12]; [11].

\begin{tabular}{|l|r|r|r|r|r|}
\hline Year & $\begin{array}{c}\text { Government } \\
\text { borrowing } \\
\text { requirement R } \\
\text { millions } \\
\text { (a) }\end{array}$ & $\begin{array}{c}\text { Government } \\
\text { revenue R } \\
\text { millions }\end{array}$ & $\begin{array}{c}\text { Total R } \\
\text { millions }\end{array}$ & $\begin{array}{c}\text { Borrowing (i-t) } \\
\text { proportion }\end{array}$ & $\begin{array}{c}\text { Tax revenue } \\
\text { (t) proportion }\end{array}$ \\
\hline 2001 & 18,352 & 215,592 & 233,944 & $\frac{(\mathrm{a})}{(\mathrm{c})}$ & 0.08 \\
\hline 2002 & 14,804 & 248,101 & 262,905 & 0.06 & 0.92 \\
\hline 2003 & 12,644 & 278,885 & 291,529 & 0.04 & 0.96 \\
\hline 2004 & 29,874 & 298,870 & 328,744 & 0.09 & 0.91 \\
\hline 2005 & 21,252 & 347,352 & 368,604 & 0.06 & 0.94 \\
\hline
\end{tabular}

Table 3: Calculation of weights

Sources: [12]; [11]. 


\begin{tabular}{|l|r|r|r|r|r|}
\hline Year & $\begin{array}{c}\text { Final } \\
\text { consumption } \\
\text { expenditure } \\
\text { R millions }\end{array}$ & $\begin{array}{c}\text { Gross savings } \\
\text { R millions }\end{array}$ & $\begin{array}{c}\text { Total } \\
\text { R millions }\end{array}$ & $\begin{array}{c}\text { Final } \\
\text { consumption } \\
\text { expenditure } \\
\text { proportion } \\
(1-s) \\
\text { (a) }\end{array}$ & $\begin{array}{c}\text { Gross } \\
\text { savings } \\
\text { proportion } \\
\text { (s) }\end{array}$ \\
\hline 2001 & 826,080 & 157,204 & 983,284 & 0.84 & 0.16 \\
\hline 2002 & 937,392 & 195,158 & $1,132,550$ & 0.83 & 0.17 \\
\hline 2003 & $1,028,545$ & 196,234 & $1,224,779$ & 0.84 & 0.16 \\
\hline 2004 & $1,143,772$ & 195,302 & $1,339,074$ & 0.85 & 0.15 \\
\hline 2005 & $1,275,335$ & 208,705 & $1,484,040$ & 0.86 & 0.14 \\
\hline
\end{tabular}

Table 4: Calculation of discount rate weights - (s) and (1-s)

Sources: [12]; [11]

\section{SUMMARY RESULTS OF APPLYING THE DECISION-MAKING CRITERIA}

When the above estimates of costs, benefits, and the social discount rate were incorporated into the equations for the three CBA decision-making criteria (NPV, IRR, BCR) over a twenty-year period, the results below were obtained.

\begin{tabular}{|l|c|c|c|}
\hline \multirow{2}{*}{$\begin{array}{l}\text { Cable waste recycling } \\
\text { project: recycling of } \\
\text { plastic }\end{array}$} & NPV & IRR (\%) & \multicolumn{2}{|c|}{ BCR } \\
\cline { 2 - 4 } & R143,434.40 & $5 \%$ & 0.91 \\
\cline { 2 - 4 } & & \multicolumn{2}{|c|}{$5 \%$ criteria } \\
\hline
\end{tabular}

Table 5: Summary of results

\section{SENSITIVITY ANALYSIS}

In many cases it is not known what the environmental repercussions of carrying out a specific investment project would be. The framework of much environmental policy is characterissed by uncertainty regarding the effect and irreversibility of some effects. The issue of uncertainty in cost-benefit analysis may be addressed, to some extent, by means of sensitivity analysis. According to this type of analysis, changes are made to the values of particular variables (for example, certain costs or benefits, or the social discount rate), after which variations in the measures of project worth (i.e. the NPV, IRR, and BCR) are revealed.

A limited sensitivity analysis was carried out in this study to estimate the effects on the measures of project worth mentioned above by varying the social discount rate.

\section{The social discount rate}

In conducting the sensitivity analysis on the social discount rate, the rate was varied by two percent above and below the derived social discount rate. The results are displayed in Table 6 below. 


\begin{tabular}{|l|r|r|r|}
\hline \multirow{2}{*}{} & \multicolumn{3}{|c|}{ CBA criteria } \\
\cline { 2 - 4 } & NPV & \multicolumn{1}{|c|}{ IRR } & BCR \\
\hline Sensitivity on social discount rate & & & \\
$\mathbf{4 . 7 2 \% ( - 2 \% )}$ & $\mathrm{R} 304,053.46$ & $12 \%$ & 0.94 \\
$\mathbf{6 . 7 2 \%}$ (derived) & $\mathrm{R} 143,434.40$ & $5 \%$ & 0.91 \\
$\mathbf{8 . 7 2} \%$ (+2\%) & $\mathrm{R} 17,683.73$ & $1 \%$ & 0.88 \\
\hline
\end{tabular}

Table 6: Sensitivity analysis: Social discount rate

From the above results it can be seen that the NPV is greater than zero in all cases. The IRR is greater than the social discount rate when the latter is reduced by $2 \%$. However, when the social discount rate is increased by $2 \%$, the IRR is less than the aforementioned rate. In all cases the BCR is less than unity. Based on the above, the project cannot be classified as an unqualified success.

For the project assessed in this paper, the NPV was greater than zero, the BCR was less than 1 and the IRR was less than the social discount rate. Due to the ambiguity of the results, caution should be applied so as not to provide unqualified support for the project.

\section{CONCLUSION AND RECOMMENDATIONS}

The authors are inclined to want recycling projects to go ahead, and still feel this way about the cable waste recycling project dealt with in this study. However, the cost-benefit analysis of extending an existing recycling plant so as to accommodate the recycling of the plastic portion of cable waste only offers qualified efficiency support.

In terms of the measures of project worth, the cost-benefit analysis provides ambiguous and conflicting results: the NPV is positive, the IRR is less than the social discount rate, and the BCR is less than unity.

However, it is very important to note that this conclusion is subject to two qualifications. The first is that more work remains to be done on the evaluation of environmental (secondary) benefits arising from the recycling of the plastic fraction of cable waste. The second qualification is that, at a lower social discount rate (i.e. 4.72\%), both the NPV and IRR provide positive results.

\section{ACKNOWLEDGEMENTS}

We gratefully acknowledge the helpful comments made by anonymous referees.

\section{REFERENCES}

[1] Basel Convention. United Nations Environmental Programme (UNEP) (2002 and 2003).Technical guidelines for the identification and environmentally sound management of plastic wastes and for their disposal including technical guidelines on the environmentally sound management of plastic coated cables. http://www.basel.int/meetings/cop/cop6/cop6_21e.pdf. (Accessed 6 ${ }^{\text {th }}$ February 2006).

[2] DEAT (2000). Integrated Pollution and waste management for South Africa. Government Gazette, Vol. 417. No. 20978. Pretoria.

[3] Stats SA (2005). Economic indicators.

http://www.statssa.gov.za/keyindicators/CPI/CPIHistory.pdf. (Accessed $5^{\text {th }}$ September 2005). 
[4] SAECMA (2005). Personal communication. Edenglen, South Africa.

[5] Aberdare Cables (2003-2006). Personal communication with production personnel. Port Elizabeth, South Africa.

[6] Brent, R.J. (1996). Applied cost-benefit analysis. Edward Elgar, London.

[7] Lancaster, K.J. (1966). A new approach to consumer theory. The Journal of Political Economy, Vol. 74, No. 2 (Apr., 1966), pp. 132-157.

[8] Rosen, S. (1974). Hedonic prices and implicit markets: Product differentiation in pure competition. Journal of Political Economy, January-February 1974, 82(1), pp. 34-55.

[9] Ready, R.C. (2005). Do landfills always depress nearby property values? Rural development paper No 27.

http://www.nercrd.psu.edu/Publications/rdppapers/rdp27.pdf. $\quad$ (Accessed $23^{\text {rd }}$ November 2006).

[10] Du Preez, M. \& Lottering, T. (2009). Determining the negative effect on house values of proximity to a landfill site by means of an application of the hedonic pricing method. South African Journal of Economic and Management Sciences, 12 (2), $256-262$.

[11] Du Preez, M. (2004). The discount rate for public sector conservation projects in South Africa. African Development Review, 16 (3), 456-471.

[12] South African Reserve Bank (December 2004, June 2005, December 2005 and March 2006). Quarterly Bulletin. SARB, Pretoria. 


\section{APPENDIX A}

\section{Electricity costs}

The total power requirements for the extrusion process involved in recycling the plastic will not be more than $90 \mathrm{~kW}$.

It is assumed that the extrusion process, once running, will only consume $75 \%$ of the installed power of the machine ${ }^{7}$. Power consumption per hour is calculated as follows:

Power consumptio $\mathrm{n}=$ Installed power $* 75 \%=90 \mathrm{~kW} * 0.75=67.5 \mathrm{~kW}$ per hour.

It is assumed that the plant will run for eight hours a day and five days a week. The plant will also only run for 45 weeks of the year. The total annual electricity consumption will be:

$$
E_{A}=P_{h}{ }^{*} H_{d}{ }^{*} D_{w} * W_{y}(1)
$$

where:

$\mathrm{E}_{\mathrm{A}}=$ total annual electricity consumption

$\mathrm{P}_{\mathrm{h}}=$ power consumption per hour

$\mathrm{H}_{\mathrm{d}}=$ daily run time in hours

$D_{w}=$ days per week that the plant operates

$\mathrm{W}_{\mathrm{y}}=$ weeks per year that the plant operates

$\mathrm{E}_{\mathrm{A}}=67.5 \mathrm{~kW} * 8$ hours $* 5$ days $* 45$ weeks $=121500 \mathrm{~kW}$ of power consumed per annum

The cost per $\mathrm{kWh}$ is R0.22, giving a total annual cost for electricity consumption of:

Total cost per annum $=\mathrm{E}_{\mathrm{A}}{ }^{*}$ Cost per $\mathrm{kWh}=121,500 \mathrm{~kW} * \mathrm{R} 0.22 / \mathrm{kWh}=\mathrm{R} 26,730.00$ [5].

In respect of maximum demand, it is desirable that the plant not have a power factor of less than $0.9^{8}$. This means that the maximum demand will be:

Max Demand $=$ Total installed power $* 1 /$ Power factor $=90 \mathrm{~kW} * 1 / 0.9=100 \mathrm{kVA}$.

The cost per kVA is R41.00. This gives a monthly cost of:

Max Demand charge $/$ month $=100 \mathrm{~kW} * \mathrm{R} 41.00=\mathrm{R} 4,100.00$.

Max Demand charge $/$ year $=\mathrm{R} 4,100.00 * 12=\mathrm{R} 49,200.00$.

\footnotetext{
${ }^{7}$ The installed power is the rated power of the equipment in question and, in the case of an extruder, is made up of motor power and heating power.

${ }^{8}$ The power factor is the measure used to translate installed electrical capacity into power demanded. Electrical equipment is not $100 \%$ efficient, and so the maximum demanded power will sometimes be greater than the installed capacity. It is for this reason that a power factor is used.
} 


\section{APPENDIX B}

In calculating this revenue figure, a number of hypotheses need to be made, and a number of steps need to be undertaken. The hypotheses and steps are discussed below.

\section{Hypotheses}

The average diameter of the individual copper core is $0.5 \mathrm{~mm}$. This is based on the most common conductor size used for telephone cable [5].

The average thickness of the insulation on the copper conductor, based on the average diameter of $0.5 \mathrm{~mm}$, is $0.2 \mathrm{~mm}$ [5].

The average density of the plastic insulation is $950 \mathrm{~kg} / \mathrm{m}^{3}$.

In order to determine the Rand price of all recycled plastic in the form of fence poles, the following steps need to be taken:

1. The total mass of scrap cable intended for recycling needs to be calculated.

2. The mass of the copper conductor per meter needs to be derived.

3. The mass of the plastic insulation per meter, which covers the copper conductor, needs to be derived.

4. The ratio of the mass of the plastic fraction per meter to the total mass of scrap cable per meter needs to be determined.

5. The ratio established in point 4 then needs to be multiplied by the total mass of scrap calculated in point 1 , to determine the mass of the plastic scrapped per month.

6. The scrap portion of plastic generated per annum must be divided by the average mass per fence pole to determine the number of poles that can be manufactured per annum.

7. The number of poles manufactured per annum must be multiplied by the cost per fence pole.

\section{Step 1:}

Total mass of scrap cable $=$ mass of jelly-impregnated cable + mass of insulated cable $=$ $15,4664 \mathrm{~kg}+279,902 \mathrm{~kg}=434,566 \mathrm{~kg}$.

\section{Step 2:}

The mass of the copper conductor per meter is derived from Equation 1 below:

$$
\dot{\mathrm{M}}_{c_{u}}=\delta_{c_{u}} \times A_{c_{u}}
$$

where:

$\dot{\mathrm{M}}_{\mathrm{Cu}}=$ the mass of the copper conductor in $\mathrm{kg} / \mathrm{m}$.

$\delta_{\mathrm{Cu}}=$ the density of copper in $\mathrm{kg} / \mathrm{m}^{2}$.

$\mathrm{A}_{\mathrm{Cu}}=$ the cross sectional area of the copper conductor in $\mathrm{m}^{2}$.

Therefore $\dot{\mathrm{M}}_{\mathrm{Cu}}=8000 \times \pi \times \frac{\left(0.5 \times 10^{-3}\right)^{2}}{4}$

$\dot{\mathrm{M}}_{\mathrm{Cu}}=0.00157 \mathrm{~kg} / \mathrm{m}$

The mass of one core kilometer $(\mathrm{ckm})$ of conductor is therefore $1.57 \mathrm{~kg}$. 


\section{Step 3:}

The mass of the plastic fraction of the coated conductor is derived from Equation 2 below:

$\dot{\mathrm{M}}_{\mathrm{P}}=\delta_{\mathrm{P}} \times \mathrm{A}_{\mathrm{P}}$

where:

$\dot{\mathrm{M}}_{\mathrm{P}}=$ the mass of the plastic in $\mathrm{kg} / \mathrm{m}$.

$\delta_{P}=$ the density of the plastic in $\mathrm{kg} / \mathrm{m}^{2}$.

$\mathrm{A}_{\mathrm{P}}=$ the cross sectional area of the plastic in $\mathrm{m}^{2}$.

$\therefore \dot{\mathrm{M}}_{\mathrm{P}}=950 \times \pi \times \frac{\left[\left(0.9 \times 10^{-3}\right)^{2}-\left(0.5 \times 10^{-3}\right)^{2}\right]}{4}$

$\dot{\mathrm{M}}_{P}=4.17 \times 10^{-4} \mathrm{~kg} / \mathrm{m}$

The mass of one core kilometer $(\mathrm{ckm})$ of plastic is therefore $0.417 \mathrm{~kg}$.

\section{Steps 4 and 5:}

Based on the above, the average mass of plastic scrapped per annum is:

$\frac{\text { Mass of plastic fraction }}{\text { Total mass }} \times$ Total mass of Scrap $=\frac{0.417}{(0.417+1.57)} \times 434566=91200 \mathrm{~kg} / \mathrm{annum}$.

\section{Step 6:}

The average mass of a pole is $3.32 \mathrm{~kg}$. The scrap portion of plastic generated per annum is $91,200 \mathrm{~kg}$ (see Steps 4 and 5 above). This implies:

Number of droppers manufactured $=(91,200 \mathrm{~kg}$ plastic $/$ annum $) / 3.32 \mathrm{~kg} / \mathrm{dropper}=27,470$ poles manufactured per annum.

\section{Step 7:}

The average cost per pole is R9.25. Therefore,

Total revenue from sale of droppers per annum $=27,470$ poles * $\mathrm{R} 9.25 /$ pole

$=\mathrm{R} 254,097.00$ [5]. 